VIII ${ }^{\text {èmes }}$ Journées Nationales Génie Civil - Génie Côtier, Compiègne, 7-9 septembre 2004

\title{
Bitung as a Future Hub Port in The Eastern Part of Indonesia
}

\author{
Prasetyadi(a), Rheo Hary Widianto(b)
}

(a)Assistant Senior Manager, Indonesia Port Coorporation IV

(b)Staff of Port Planning, Indonesia Port Coorporation IV

\begin{abstract}
$\underline{\text { Abstract }}$
The issue of the development in eastern part of Indonesia is complicated. For the last 10 years, the eastern part of Indonesia has become a central point in the context of national development, considering its limitations in several economy and social sectors. In spite of its abundant natural resources, in some aspects of development the eastern part of Indonesia is left behind the western part, indicated as follows : a. Respectively only $15 \%$ and $9 \%$ of the local and foreign investment is absorbed in this area, while the rest is given to the western area.; b.The quality of human resource in eastern part of Indonesia is below the national average. One of the dominant constraints faced by the eastern part of Indonesia in economic development is that export commodities from this area should go first to Tanjung Priok in Jakarta and Tanjung Perak in Surabaya, while in fact it is nearer for the cargo to reach their destination countries, especially in Asia Pacific region, from the eastern part of Indonesia. It resulted in the high transportation cost and it is difficult for products from the eastern Indonesia to compete in the global market, as well.
\end{abstract}

\section{Preface}

\subsection{General}

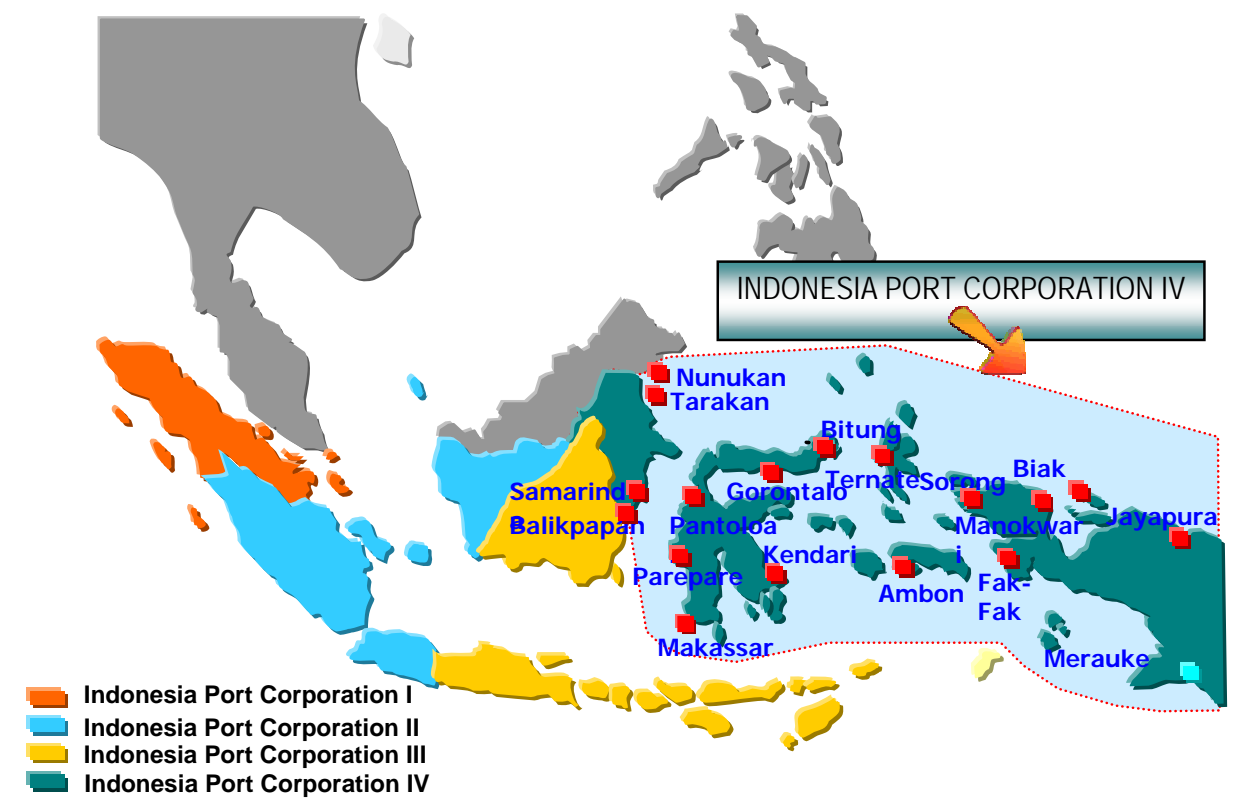

Figure 1. Areas of Indonesia Port Corporation (IPC) 


\subsection{Container Movement In Indonesia}

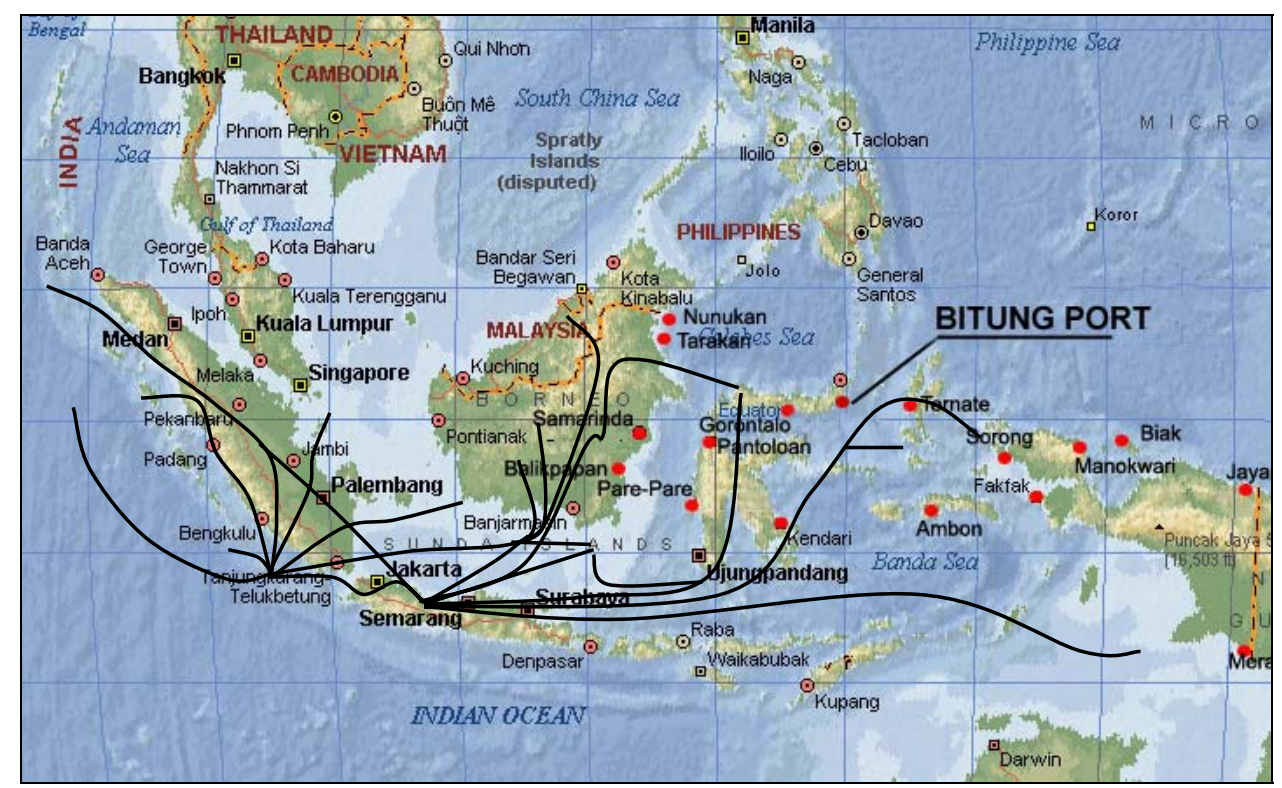

Figure 2.Existing Condition of Container Sea Transportation Network

Table 1. Container Traffic at Major Port In Indonesia

\begin{tabular}{|c|c|c|c|c|c|c|}
\hline \multirow{2}{*}{ No } & \multirow{2}{*}{$\begin{array}{l}\text { NAME OF } \\
\text { PORTS }\end{array}$} & \multicolumn{4}{|c|}{ YEAR (TEUs) } & \multirow{2}{*}{ REMARKS } \\
\hline & & 2000 & 2001 & 2002 & $2003^{*}$ & \\
\hline A. & IPC I : & & & & & \\
\hline 1 & Belawan & 312.781 & 372.883 & 408.666 & 437.847 & \\
\hline 2 & Pekanbaru & 86.721 & 98.354 & 117.946 & 170.366 & \\
\hline \multirow[t]{2}{*}{3} & Dumai & 464 & 170 & 217 & 313 & \\
\hline & Total IPC I : & 399.966 & 471.407 & 526.829 & 608.527 & \\
\hline B. & IPC II : & & & & & \\
\hline 1 & Tanjung Priok & 2.494 .596 & 2.524 .396 & 2.607 .144 & 2.968 .230 & \\
\hline 2 & Panjang & 7.690 & 76.469 & 76.134 & 103.782 & \\
\hline \multirow[t]{2}{*}{3} & Pontianak & 83.093 & 100.813 & 112.240 & 121.206 & \\
\hline & Total IPC II : & 2.585.379 & 2.701 .678 & 2.795 .518 & 3.193.218 & \\
\hline C. & IPC III : & & & & & \\
\hline 1 & TPKS Semarang & 0 & 135.467 & 315.071 & 320.000 & \\
\hline 2 & Tanjung Perak & 305.514 & 399.928 & 341.480 & 586.432 & \\
\hline 3 & Banjarmasin & 0 & 138.840 & 149.302 & 159.500 & \\
\hline 4 & Benoa & 0 & 19.972 & 22.413 & 24.500 & \\
\hline 5 & Sampit & 0 & 11.188 & 18.276 & 20.453 & \\
\hline 6 & Tenau Kupang & 0 & 7.840 & 8.865 & 10.750 & \\
\hline 7 & TPS Surabaya & 0 & 876.136 & 936.166 & 1.500 .000 & \\
\hline \multirow[t]{2}{*}{8} & BJTI Surabaya & 0 & 0 & 511.953 & 682.600 & \\
\hline & Total IPC III : & 305.514 & 1.589.371 & 2.303 .526 & 3.304 .235 & \\
\hline D. & IPC IV : & & & & & \\
\hline 7 & Makassar & 164.684 & 177.416 & 208.384 & 221.479 & \\
\hline 8 & Bitung & 66.737 & 80.386 & 84.680 & 87.894 & \\
\hline 9 & Balikpapan & 22.401 & 34.210 & 52.632 & 55.540 & \\
\hline \multirow[t]{3}{*}{10} & Samarinda & 68.685 & 71.618 & 88.043 & 132.887 & \\
\hline & Total IPC IV : & 322.507 & 363.630 & 433.739 & 497.800 & \\
\hline & Total IPC I $\sim$ IV & 3.613 .366 & 5.126 .086 & 6.059 .612 & 7.603 .780 & \\
\hline
\end{tabular}

*estimated 
Table 2. Container handling movement by composition in Indonesia

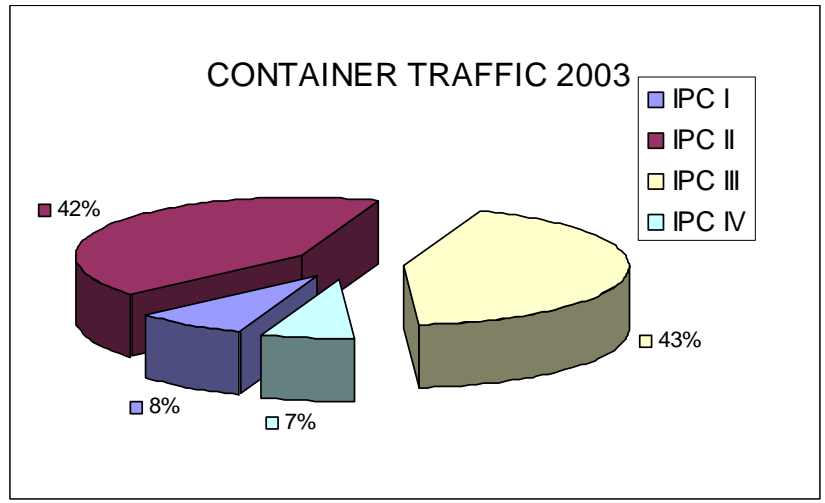

\section{The Existing Condition of Bitung Port}

\subsection{Existing Port Facilities}

Container Terminal

\begin{tabular}{|l|r|}
\hline Wharf & $130 \mathrm{M}$ \\
\hline Stacking Yard & $44.000 \mathrm{M}^{2}$ \\
\hline Traditional Wharf & $60 \mathrm{M}$ \\
\hline CFS and & 42 X 30 M \\
\hline $\begin{array}{l}\text { Head Truck UNIT } \\
\text { Chasis }\end{array}$ \\
\hline Top Lifter & 1 UNIT \\
\hline Forklift 5 Ton & 1 UNIT \\
\hline Tug Boat 1.500 HP \\
\hline $\begin{array}{l}\text { Mooring Boat 160 } \\
\text { HP }\end{array}$ \\
\hline Pilot Boat & 1 UNIT \\
\hline
\end{tabular}

\begin{tabular}{|l|r|}
\hline Reach Stacker, 48 Ton & 1 Unit \\
\hline $\begin{array}{l}\text { Crane Mobile, 150 Ton } \\
\text { \& 25 Ton }\end{array}$ & 2 Unit \\
\hline Forklift 28 Ton & 3 Unit \\
\hline $\begin{array}{l}\text { Forklift 7, 3.5 \& 2 } \\
\text { Ton }\end{array}$ & @ Unit \\
\hline Forklift 5 Ton & 4 Unit \\
\hline Forklift 3 Ton & 3 Unit \\
\hline
\end{tabular}

Conventional Terminal

\begin{tabular}{|c|c|}
\hline Wharf & \\
\hline - Ocean Going & $605 \mathrm{M}$ \\
\hline - Domestic & $602 \mathrm{M}$ \\
\hline - Chemical Industry & $146 \mathrm{M}$ \\
\hline - Traditional & $60 \mathrm{M}$ \\
\hline Container Wharf & \\
\hline - Conblock Yard & $27.311 \mathrm{M}^{2}$ \\
\hline - Hotmix Yard & $2.735 \mathrm{M}^{2}$ \\
\hline Transhit shed & $13.392 \mathrm{M}^{2}$ \\
\hline Passenger Terminal & $3.195 \mathrm{M}^{2}$ \\
\hline Mobile Crane 25 Ton & 1 Unit \\
\hline $\begin{array}{l}\text { Reach Stacker } 42 \\
\text { Ton }\end{array}$ & 1 Unit \\
\hline Forklift 5, 3, \& 2 Ton & @1 Unit \\
\hline Fire Fighting 25 Ton & 1 Unit \\
\hline Tronton 18 Ton & 2 Unit \\
\hline Electricity & $99 \mathrm{KVA}$ \\
\hline $\begin{array}{l}\text { Water } \\
\text { (owned) }\end{array}$ & 200 Ton/Hour \\
\hline Water Supply (PAM) & 100 Ton/Hour \\
\hline Tug Boat (1.160 HP) & 2 Unit \\
\hline Pilot Boat & 2 Unit \\
\hline Barge & 1 Unit \\
\hline
\end{tabular}




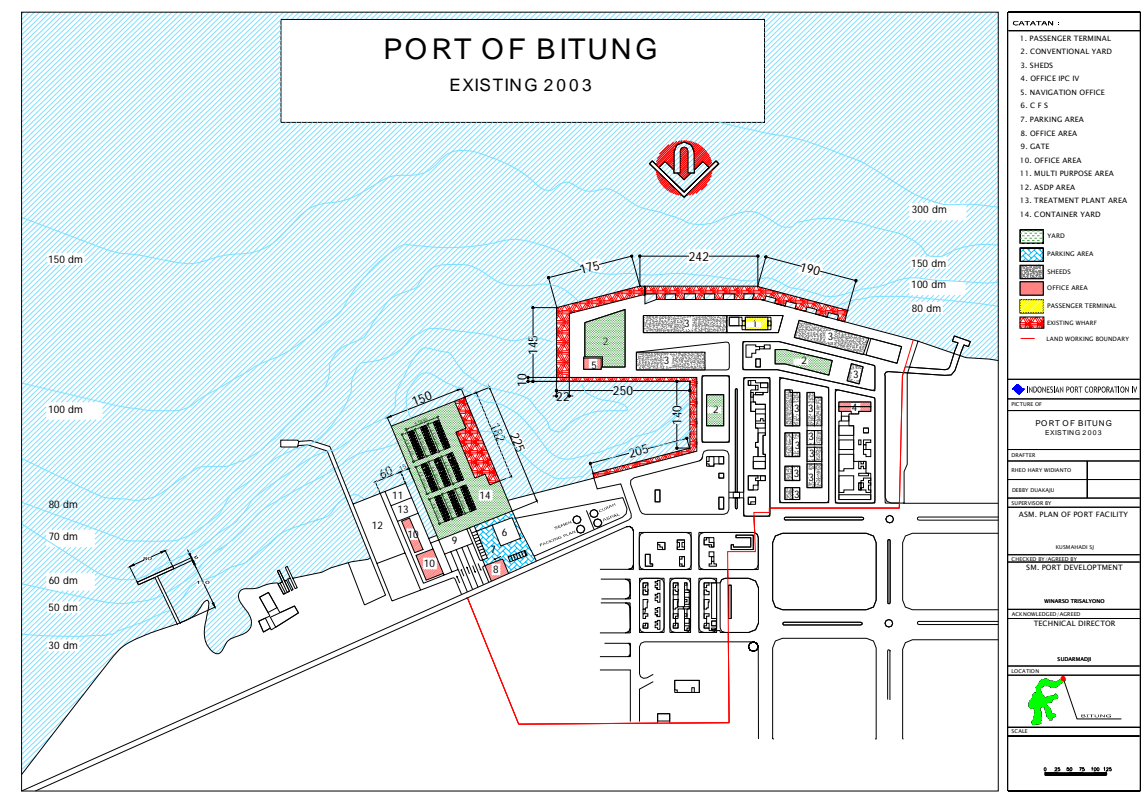

Table 3. Container handling movement by composition in Indonesia

\subsection{Container Traffics Container Cargoes at Bitung Port}

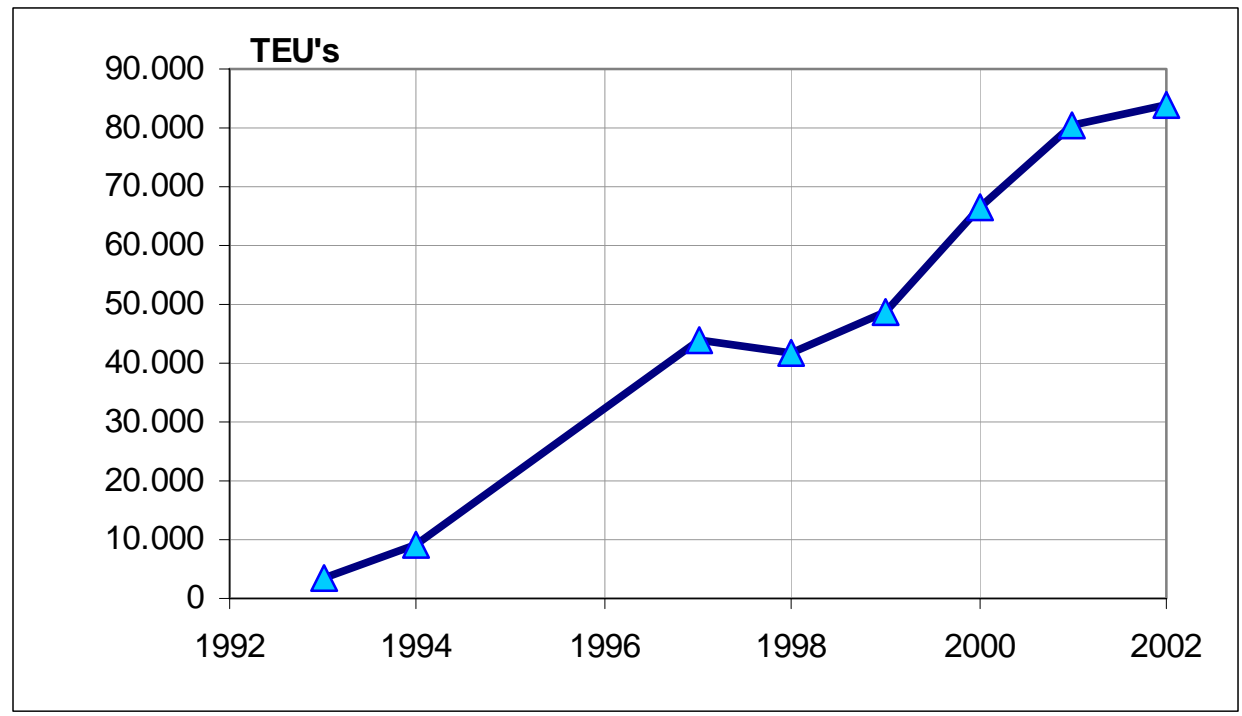

Figure3 Container Cargo Throughput at Bitung Port (TEU’s) (1993-2002) 


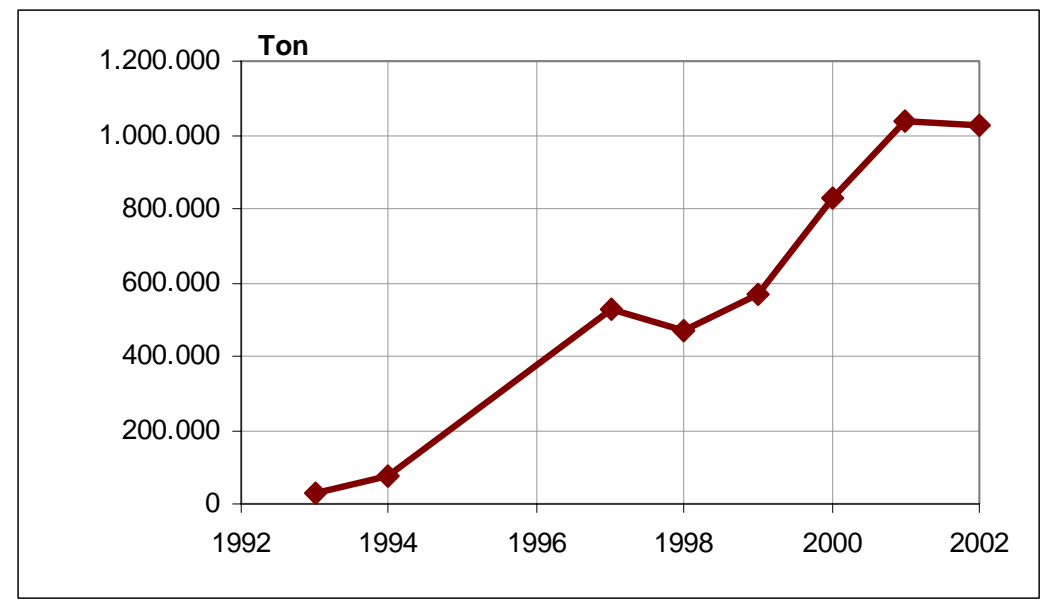

Figure 4 Container Cargo Throughput at Bitung Port (Ton) (1993-2002)

Table 4 Container Cargo Traffic at the ports of Bitung,

Balikpapan, Samarinda, Tarakan, Pantoloan, Gorontalo, Kendari, Ternate, Ambon

\begin{tabular}{|c|c|c|c|c|c|c|c|c|c|c|c|}
\hline & Unit & 1993 & 1994 & 1995 & 1996 & 1997 & 1998 & 1999 & 2000 & 2001 & 2002 \\
\hline Bitung & TEUs & 3.811 & 8.576 & 14.239 & 19.869 & 43.760 & 41.929 & 48.674 & 66.737 & 80.386 & 83.861 \\
\hline Pantoloan & TEUs & 44 & 435 & 660 & 1.423 & 5.977 & 6.908 & 8.740 & 15.083 & 20.791 & 28.348 \\
\hline Gorontalo & TEUs & 0 & 0 & 0 & 0 & 0 & 0 & 0 & 0 & 0 & 0 \\
\hline Kendari & TEUs & 211 & 295 & 804 & 1.467 & 2.502 & 74 & 40 & 0 & 6.216 & 8.216 \\
\hline Ternate & TEUs & 422 & 550 & 1.608 & 2.734 & 4.914 & 4.244 & 5.068 & 2.112 & 2.504 & 3.691 \\
\hline Ambon & TEUs & 971 & 1.207 & 2.124 & 7.257 & 15.092 & 13.630 & 6.634 & 12.607 & 18.452 & 21.139 \\
\hline Tarakan & TEUs & 0 & 0 & 0 & 0 & 0 & 0 & 0 & 0 & 16.014 & 17.454 \\
\hline Balikpapan & TEUs & 3.111 & 4.133 & 4.245 & 7.641 & 28.583 & 13.435 & 20.684 & 22.401 & 34.210 & 52.632 \\
\hline Samarinda & TEUs & 1.513 & 1.296 & 1.450 & 28.499 & 52.413 & 50.548 & 54.569 & 68.685 & 71.618 & 88.043 \\
\hline TOTAL & TEUs & 57.079 & 90.219 & 114.469 & 140.569 & 245.732 & 130.768 & 145.323 & 189.788 & 256.088 & 313.543 \\
\hline
\end{tabular}

\section{Bitung Port Developtment Plan}

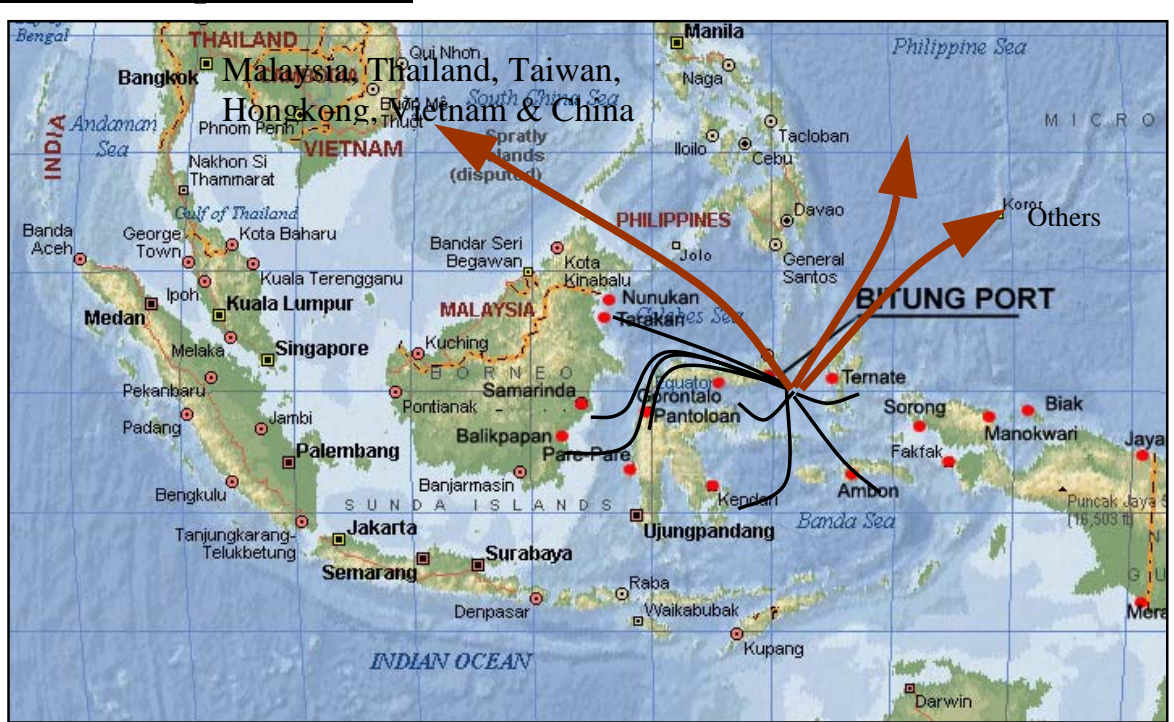

Figure 5 Interaction between Bitung Port and other ports in Container Sea Transportation Network Nearby International Linkage Area 


\subsection{Forecasting of Container Cargoes}

Table 5 Container Forecast at Bitung, Balikpapan, Samarinda, Ambon, Pantoloan, Ternate, Kendari, Tarakan, Gorontalo

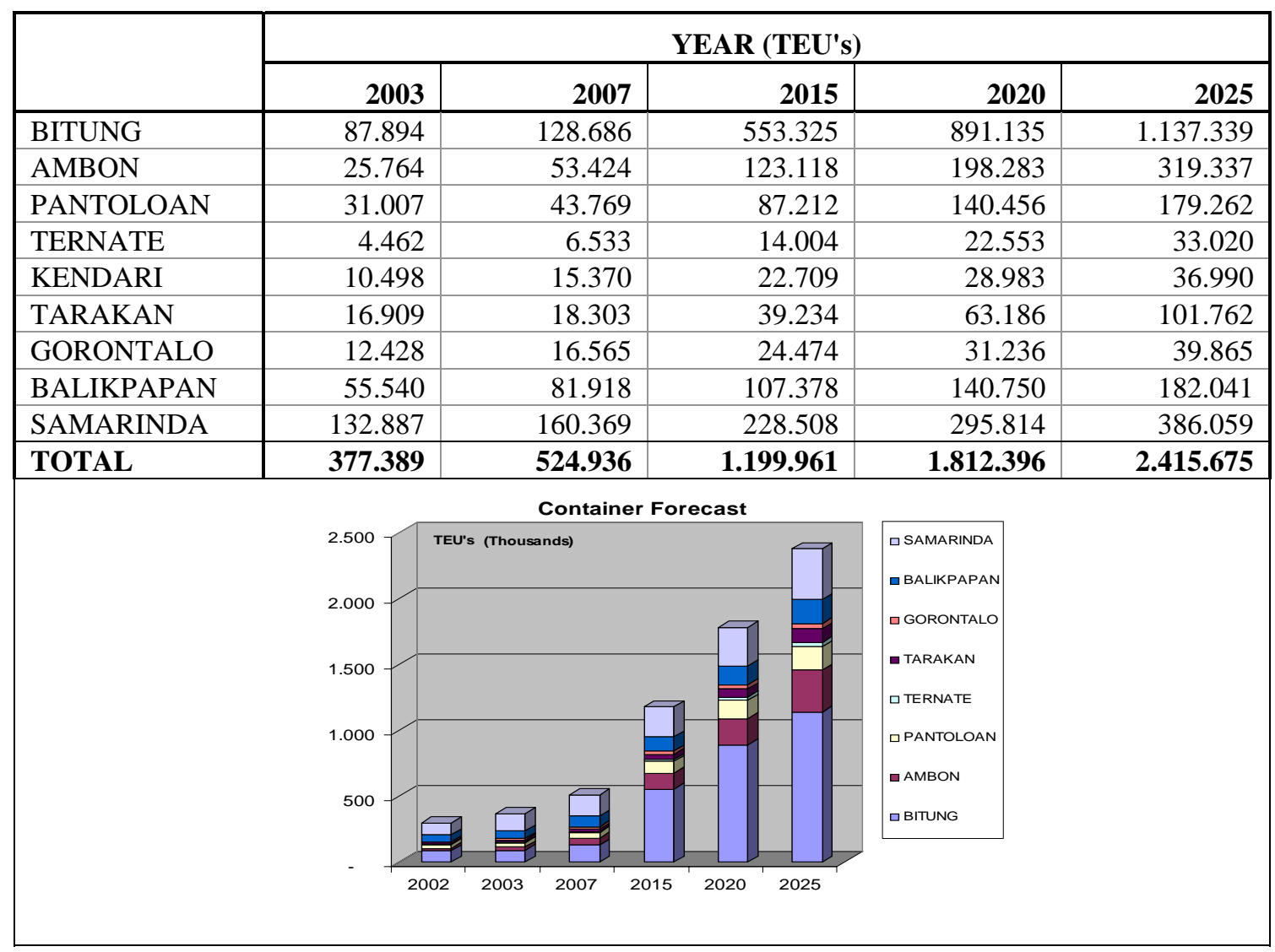

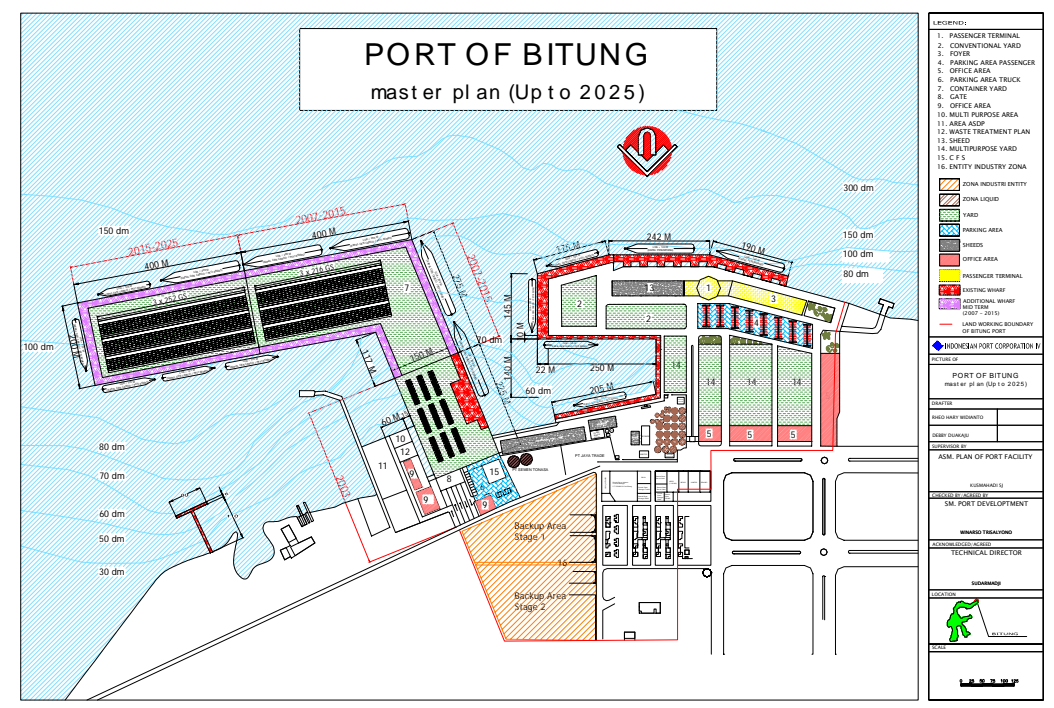


Table 6 Required Berth

\begin{tabular}{|l|l|r|r|r|r|r|}
\hline \multicolumn{2}{|c|}{ Year } & 2008 & 2013 & 2018 & 2023 & 2028 \\
\hline Container Volume & TEU & 154.000 & 202.000 & 264.000 & 342.000 & 439.000 \\
\hline No. of required berth & & 2 & 2 & 2 & 2 & 3 \\
\hline \multirow{2}{*}{ No. of crane } & Mobile crane & 2 & 2 & 2 & 2 & 2 \\
\cline { 2 - 7 } & Gantry Crane & 2 & 2 & 2 & 2 & 4 \\
\hline Berth Capacity & TEU & 362.000 & 362.000 & 362.000 & 362.000 & 588.000 \\
\hline
\end{tabular}

Developtment of Bitung Port in short term operated up to 2015:

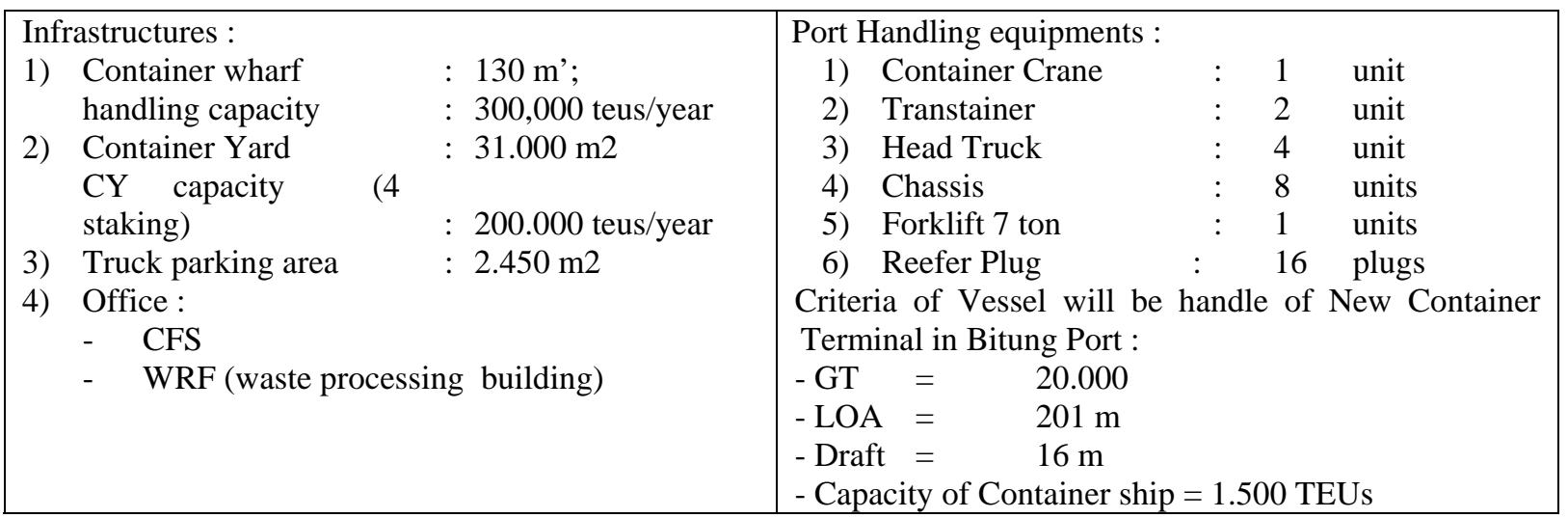

\section{The Opportunity of Bitung Port to be a Hub Port}

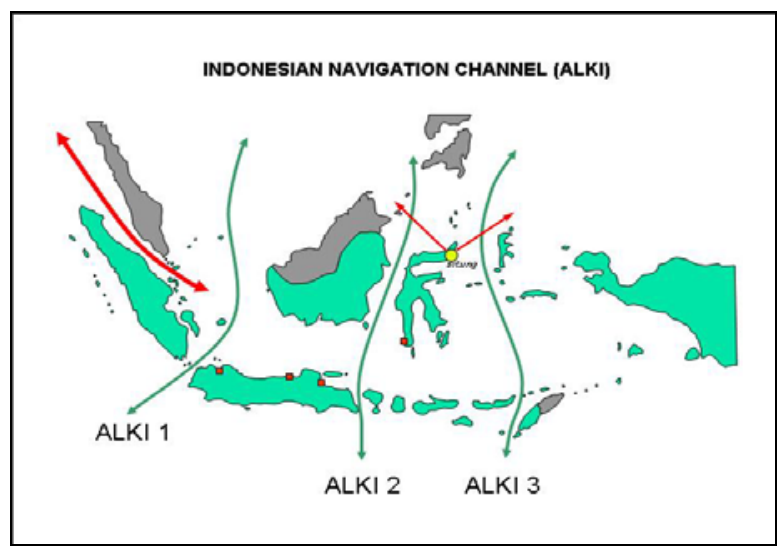

Figures 6 Indonesian Navigation Channel 
Table 7 Gross Regional Domestic Products (GRDP) of North Sulawesi Province at Constant Prices by Origin

\begin{tabular}{|c|c|c|c|c|c|c|c|c|c|c|}
\hline \multirow[b]{2}{*}{ No } & \multirow{2}{*}{$\begin{array}{c}\text { Industrial } \\
\text { Origin }\end{array}$} & \multicolumn{9}{|c|}{ Year (Million Rp.(1993 Prices)) } \\
\hline & & 1993 & 1994 & 1995 & 1996 & 1997 & 1998 & 1999 & 2000 & 2001 \\
\hline \multirow[t]{7}{*}{1} & Agriculture & 775,1 & 829,8 & 902,0 & 974,3 & 1006,1 & 1004,9 & 1046,2 & 1101,8 & 882,6 \\
\hline & a) food Crop & 303,0 & 320,4 & 337,8 & 356,7 & 347,4 & 325,6 & 342,9 & 346,7 & 272,6 \\
\hline & b) Plantation & 263,7 & 277,1 & 302,6 & 324,2 & 343,7 & 366,3 & 358,6 & 381,6 & 391,2 \\
\hline & c) Livestock \& & & & & & & & & & \\
\hline & Products & 58,7 & 60,5 & 72,6 & 80,9 & 84,3 & 75,0 & 75,0 & 84,5 & 65,4 \\
\hline & d) Foresty & 65,6 & 74,4 & 81,4 & 90,7 & 103,5 & 105,4 & 102,8 & 99,3 & 12,3 \\
\hline & e) Fishery & 84,0 & 97,5 & 107,6 & 121,7 & 127,2 & 132,7 & 166,9 & 189,7 & 141,1 \\
\hline 2 & $\begin{array}{l}\text { Mining \& } \\
\text { Quarrying }\end{array}$ & 96,9 & 111,9 & 119,5 & 179,5 & 192,1 & 229,4 & 279,1 & 315,3 & 252,2 \\
\hline \multirow[t]{2}{*}{3} & Manufacturing & & & & & & & & & \\
\hline & $\begin{array}{l}\text { gas/oil) } \\
\text { Elect, gas \& }\end{array}$ & 238,3 & 260,5 & 286,9 & 315,8 & 336,3 & 353,8 & 371,2 & 395,2 & 301,7 \\
\hline 4 & $\begin{array}{l}\text { Watersupply } \\
\text { Trade, }\end{array}$ & 16,9 & 18,8 & 22,0 & 25,2 & 28,0 & 29,2 & 31,2 & 32,6 & 27,1 \\
\hline 5 & $\begin{array}{l}\text { Restaurant \& } \\
\text { Hotel } \\
\text { Transport \& }\end{array}$ & 302,9 & 337,4 & 378,2 & 441,7 & 435,3 & 461,6 & 488,4 & 521,5 & 415,2 \\
\hline 6 & Communication & 391,3 & 414,4 & 456,2 & 493,2 & 526,9 & 540,0 & 561,9 & 587,5 & 539,5 \\
\hline \multirow[t]{4}{*}{7} & $\begin{array}{l}\text { Banking \& } \\
\text { financial } \\
\text { services }\end{array}$ & 151,4 & 164,5 & 176,5 & 190,7 & 200,5 & 87,5 & 121,2 & 141,2 & 99,3 \\
\hline & a) Banking & 57,1 & 64,4 & 68,9 & 75,6 & 78,2 & $-27,3$ & 0,2 & 15,0 & 3,3 \\
\hline & $\begin{array}{l}\text { b) Non Banking } \\
\text { c) Rental \& }\end{array}$ & 9,9 & 10,4 & 11,1 & 11,8 & 12,6 & 11,5 & 12,2 & 12,8 & 9,2 \\
\hline & Company & 841 & 7 & 066 & 1922 & 7 & $?$ & 1080 & 11 & 860 \\
\hline \multirow{2}{*}{8} & Properties 7 & & & & & & & & & \\
\hline & Construstion & 302,2 & 331,9 & 364,7 & 400,7 & 432,1 & 363,2 & 367,4 & 379,8 & 341,1 \\
\hline 9 & $\begin{array}{l}\text { Public Admin } \\
\text { \& Defense }\end{array}$ & 531,8 & 548,9 & 565,8 & 583,6 & 497,7 & 497,1 & 505,3 & 515,5 & 403,1 \\
\hline \multirow[t]{2}{*}{10} & $\begin{array}{l}\text { Services } \\
\text { (Private/Social } \\
\text { \& Recreation) }\end{array}$ & 94,8 & 97,7 & 101,4 & 105,0 & 112,1 & 111,2 & 117,7 & 126,8 & 95,7 \\
\hline & TOTAL & $2.901,8$ & $3.115,9$ & $3.373,4$ & $3.709,7$ & $3.767,0$ & $3.677,9$ & $3.889,7$ & $4.117,1$ & $3.357,5$ \\
\hline
\end{tabular}




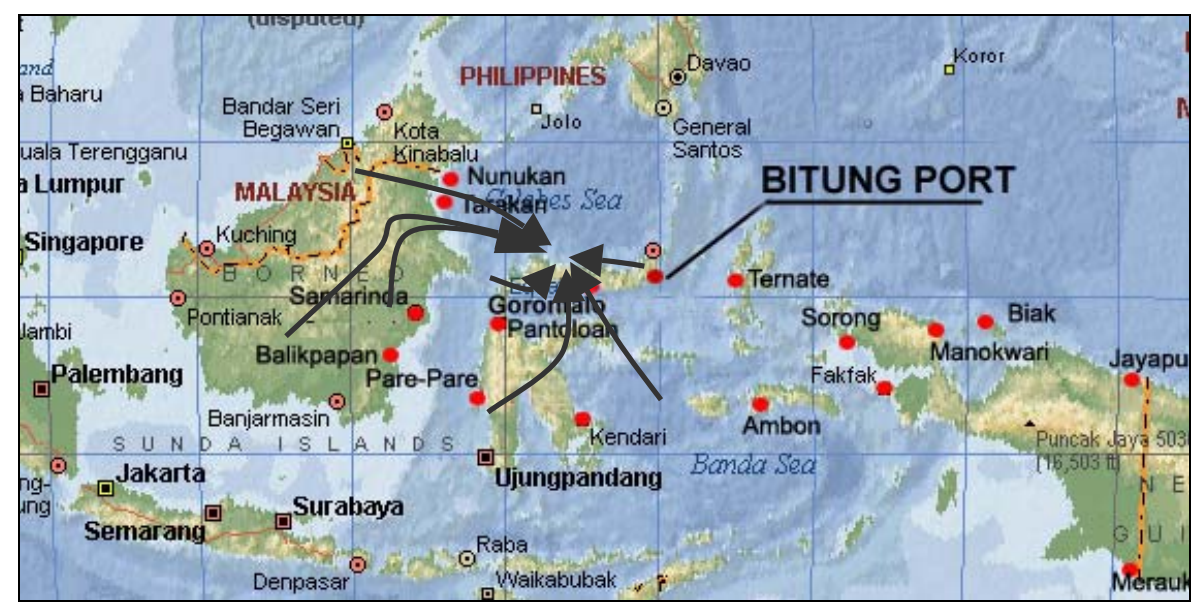

Figure 7 Interaction - Connection of Bitung Port

\subsection{Manufacturing}

The manufacturing of hinterland bitung came from port of Ambon, Ternate Agriculture, industry \& mining product

East Kalimantan (Samarinda, Balikpapan, Tarakan, Nunukan) also has significant contributions for cargo to port of Bitung such as world products, coal, oil \& containerization plywood.

Strenght of Bitung Port

1. Located directly alongside the Pacific Ocean;

2. Natural port;

3. Suitable infrastructure and superstructure available;

4. Located in Indonesian Navigation Channel

\subsection{The Fundamentals Factor to be a Hub Port}

Based on the above explanation, question occurs is "Is Bitung Port possible to become a hub ports in Indonesia?

There are fundamental factors required to be considered :

a.Geographical position and location

Positioned at $01^{\circ} 26^{\prime} 00^{\prime \prime} \mathrm{N}$ and $125^{\circ} 11^{\prime} 00^{\prime \prime}$ E, in the island of Sulawesi, closed with the Philippines, and having the nearest distance to Europe and Asia Pacific. As one of ports in Indonesia located at Navigation Channels 2 (ALKI 2), Bitung Port is very strategic as Makassar Strait is in the center of Indonesia archipelago, connecting the western with the eastern region of Indonesia.

Taking the strategic position into consideration, in the future Bitung Port will be prepared to become an hub port handling local cargo transportation, and a transshipment port, supported also by the potential of hinterland and surrounding ports.

b.Hydro oceanography of Bitung Port

Navigation Channel :

The length of the channels is 9 mile, width 600 meters and the depth 12 to $15 \mathrm{~m}$ LWS. And the condition of sea bed is Sand/Clay.

Basin : 
Bitung port has a basin with the total area 4,5 hectares, and the draught $-7,00$ to $-15,00 \mathrm{~m}$ LWS. The draught can be handle the container vessel, with capacity more than 3,000 teu $(40,000$ DWT).

c.Cargo potential surrounding Port of Bitung

The cargo flow within the period of 1993 to 2002 through other ports around Bitung such as Gorontalo, Pantoloan, Ambon, Ternate, Kendari, Tarakan and in Bitung itself indicated an average increase of 5\% per year, meaning that interisland trading activities in the eastern part of Indonesia was quite promising.

d.Hinterland \& hinter island potentials and growth of areas

The potentials hinterland \& hinter island of Bitung Port support the development of the port, indicated by the crop products according to GRDP data of agriculture, fishery, forestry, mining, processing, water supply products, hotel and tourism as well as transportation and communication infrastructure, in which it indicated a significant growth between $4-6 \%$ per year.

It can be concluded that the economic activities in North Sulawesi, particularly in the city of Bitung, can be expected to support the development of Bitung Port to become an international hub port.

e.Supports from other ports in Indonesia and other countries

Developing Bitung Port also relies on the contributions given by the surrounding ports. So it is expected that the whole cargo, exported or imported to/from countries in the regions of Asia Pacific, Europe, and Southeast Asia can be collected at Bitung Port to be distributed according to the destinations.

\section{Conclusion}

The first stage Construction of Container Terminal of Bitung Port will be finished at the end of 2003. That new facilities will encourage the container movement particularly in the eastern part of Indonesia, and even accelerate the optimum use of Indonesian Navigation Channel (ALKI) II.

It is required to involve capable investors to make a new network in container movement pattern in the eastern part of Indonesia.

Advantages gained from making Bitung Port a hub port, idest.

As a trigger the development of eastern areas of Indonesia so they can accelerate the regional development like in the western part of Indonesia for the future.

\section{Références}

1 Biro Rinbang, (2003). Traffic Container and General Cargo In Indonesia Port Corporation IV in 2003. IPC IV.

2 Technical Direktorat, (2003). Master Plan of Indonesia Port Corporation IV. IPC IV.

3 Bitung Local Government, (2003). Bitung in Statistics. Statistics Center.. 